\title{
MARKETING ANALYSIS OF SOCIAL MEDIA - DEFINITION CONSIDERATIONS
}

\author{
BARBARA MRÓZ-GORGON̂N, ${ }^{1}$ KAMILA PESZKO ${ }^{2}$
}

RECEIVED

ACCEPTED

JEL

CLASSIFICATION

KEYWORDS

ABSTRACT

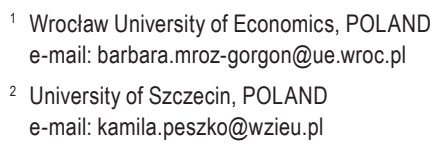

2 University of Szczecin, POLAND

e-mail: kamila.peszko@wzieu.pl

15 January 2016

1 November 2016

M31, M37

social media, definition, communication channels, marketing

Social media are playing an increasingly important role in the life of every internet user and the companies. They are one of the main source of information, provide interaction and/or integration. The authors present the history and evolution of social media which are the basis for further considerations. The objective of the paper is analysis of the definitions in the context of new communication channels or the functionality of already existing social media. The result of the analysis is the author's definition, includes the most important aspects of the currently existing social media.

\section{Introduction}

The idea of using mass media in order to create some kinds of social group, movements and transform them into consumer trend has been the topic of many scientific discussion since the book of J. McGinniss "The Selling of the President 1968" (McGinniss, 1969) has been published. 
In 1971, Ph. Kotler and G. Zaltman had pointed out, that social marketing (Kotler, 1975) ${ }^{1}$ is a promising framework for planning and implementing social change and that the application of commercial ideas and methods to promote social goals will be seen by many as another example of business's lack of taste and self-restrained (Kotler, Zaltman, 1971).

After a decade the concept of implementation social marketing was still treated suspiciously by many researchers, i.a.: P. N. Bloom and W. D. Novelli (Bloom, Novelli, 1981).

$\mathrm{Ph}$. Kotler and G. Zaltman noted that, the idea of that implementation will not disappear by ignoring it or ralling against it, and that the application of the logic of marketing to social goals is a natural development and on the whole a promising one (Kotler, Zaltman, 1971).

Today, thanks to the Internet and its effect - communication revolution and invention of people, like Mark Zuckerberg - the co-founder and CEO of the social-networking website Facebook, we know that the idea of using mass media (and nowadays - social media) as a channel of marketing communication happened to be the great and powerful trend which influence society and the whole market.

There are many issues related to Social Media considered and tested by many scientists around the world, i.a.: usage, barriers and measurement of social media marketing in B2B perspective (Michaelidou, Siamagka, Christodoulides, 2011) branding and marketing communication (Kaplan, Haenlein, 2010). and prediction of future models of Social Media usage (Asur, Huberman, 2011). The concept of Social Media and possibilities of its usage is the current issue- as an articles related to Social Media in many magazines connected with business practice and scientific journals; as a topic of many conferences and congresses.

The major distinguishing feature of the "new media" is the possibility of dialoguing with consumers, which is a great chance of brand idea development; however, if led improperly, such dialogues may also become threats (Mróz-Gorgoń, 2014). The meaning and use of Social Media is a very important element of marketing communication system in many companies- all over the world, especially in the era of companies which only operates through the social media channels (online).

As V. Dijk pointed out: "writing a critical history of social media is bound to be an endless, dynamic adventure" (Dijck, 2013). In 2010 A.M. Kaplan and M. Haenlein had published an article in which they proposed the definition and classification of social media; the authors also pointed out the challenges and opportunities of using social media (Kaplan, Haenlein, 2010). The article has been quoted more than 5 thousand times so far and different scientific research (social media study) had been made in many countries all over the world, and that also confirms the importance of study the phenomenon.

Through the process of systematic literature studies this article will cover the different ways of identifying Social Media in the context of their marketing communication. The main purpose of this paper is to analyze and to schematize the division of Social Media definitions.

${ }^{1} \mathrm{Ph}$. Kotler has defined social marketing as "the design, implementation, and control of programs seeking to increase the acceptability of a social idea or practice in a target group(s)". 


\section{Methodology}

As a result of the critical analysis of the literature will be presented a short history of social media and the main point of reference in the proposed social media definition. This allowed for the creation of a new definition of social media adapted to the current capabilities of their communication channels.

Main thesis of the authors in the article is: "Definitions of social media in contemporary literature do not reflect the current specifics of the phenomenon." Therefore, as the general purpose of article authors accepted the analysis of existing definitions of social media from the point of view produced in the time channels social media and to propose the current definition.

\section{Histopy and Evolution of Social Media}

Social media was further developed during the 1970s. MUD, originally known as MultiUser Dungeon, MultiUser Dimension, or Multi-User Domain, was a real-time virtual world with role-playing games, interactive fiction, and online chat. MUD is primarily text based which requires users to type commands using a natural language. BBS was created in 1978, the same year as MUD. BBS is a synonym for bulletin board system. Users log in to the system to upload and download software, read news, or exchange messages with others. Bulletin boards were the predecessors of the World Wide Web (Kaplan, Haenlein,2010). Today, in Facebook surround the greatest market leaders operates, while companies in the SME sector are in the initial phase of using social media marketing strategy (Shirky, 2011).

It is difficult to study social media without encountering the phrase social networking. Social networks have evolved over the years to the modern-day variety which uses digital media (Edosomwan et al., 2011). One of the pioneers of the network society study- J. Van Dijck (among others like: J. Martin (1978), S. Braten (1981), M. Castels (2000), explains that apart from their ability to collect (meta)data, the computational power of social media platform lies in their capability to include algorithms for processing data (Dijck, 2013) - social networks such as Facebook and Linkedln are increasingly focusing on the opportunities to provide research services. Massmarket communities have a huge potential to develop research services (Smith, 2009). The widespread of presence of social media platforms drives people to move many of their social, cultural, and professional activities to these online environments (Dijck, 2013). G. Szymański emphasize, that social media is the place of free time, social conversations, browse the curiosities and gossips, and that differs it from the time spent on shopping (Szymański, 2013). Advertising in social media channels, as L. Gracz pointed out, gives advertisers additional benefits such as reducing the distance to the recipient, descend to the level of the caller, voluntarism and commitment of user interaction (Gracz, Ostrowska, 2014).

The following infographic shows the genesis and evolution of social media (Figure 1). 
-Pheed is a social networking service that competes with Facebook, Twitter, YouTube and related ites. Founded by Internet entrepreneur OD Kobo. Pheed is aimed at a younger audience than Facebook's demographic. Pheed combines text, video, images and audio, and includes a live broadcast option. The pheeds can also be shared by Twitter, Facebook, and Gmail. The pheeds can be copyrighted which make them the user's property.

\section{Figures 1. Short history of social media}

Source: own elaboration. 


\section{Definition of Social Media and their Division}

The concept of social media encompasses a huge range of communication. It can be defined as a set of relationships, behaviors, feelings, empiricism and the interaction between consumers, brands, in which there is a multidirectional communication, exchange of experience with advanced communication tools. They are allowing the media to support and implement communication and cognitive needs of man, having a huge impact on the world and active co-creation of information distributed by the media and companies (Peszko, Chrąchol, 2011). Social networking sites give users a great amount of possibilities for interaction, integration and personalization of sites for Internet users in international and global dimension. The center of gravity from the Web has shifted towards user, who creates the service content, provides text, photos, music, comments, links to interesting websites. And that is the way to create the user community (Czubała, 2012).

Some of the authors claim, that in order to define the concept of social media, one must separately consider the importance of the two members forming the term (media and community). K. Fabjaniak-Czerniak (2012) underline, that the term media should be understood primarily traditional channels of information transmission, i.e. television, radio and newspapers. The term also refers to the way in which that information is provided to recipients media, for example: via broadcast signal, radio signal, written press and photography. However, each of these media not only disseminate information but also engages customers, linking them together in certain social groups, centered around a particular issue. Media therefore build informal communities, which are characterized by the solidarity around specific issues. Nowadays rapidly developing modern information technology made it possible to strengthen this type of relationship among members of these informal groups. In addition, a variety of mobile applications provide users of the network constantly improved tools for dialogue, which is a key element distinguishing traditional media, social media.

M. Jurkowski accentuated that social media represent the whole scope of behaviors, feelings, relationships and interactions between consumers and brands, and the omni-directional communication takes place in here in the exchange of experience using powerful tools. This type of media allows for the strengthening and implementation of communication and cognitive human needs, allowing the impact to the surrounding world and actively co information distributed by various entities (Jurkowski, 2013).

J. Kaznowski highlighted that meaning of the phenomenon can be describe as media consisting of social control that can be used on any scale, including both broadcast content and the possible points of view with regard to information (Kaznowski, 2014, as cited in Królewski, Sala, 2016).

Different approach of the definition has been pointed by T. Dryl, who emphasized, that the concept of social media refers to the socially controlled media, which are used in the communication process on any scale, direction and purpose. The difference between social and the mass media and is the ability to simultaneously communicate "one-to-many" and "one-to one". Social media are focused on dialogue, controversy, discussion and publication of information is only the beginning of the communication process. The information can be freely modified, transmitted in different directions over the next participants in the process who the recipients are broadcasting messages (Dryl, 2015).

In the article mentioned in Introduction, A.M. Kaplan and M. Haenlein defines social media as a group of Internet- based applications that build on the ideological and technological foundations of Web 2.0, and that allow the creation and exchange of user-generated content (Kaplan, Haenlein, 2010). 
Social media platforms have unquestionably altered the nature of private and public communication (Dijck, 2013). Social media can be defined as a utilizing platforms - such as content sharing sites, blogs, social networking, and wikis - to create, modify, share, and discuss Internet content. This represents the social media phenomenon, which can now significantly impact a firm's reputation, sales, and even survival (Kietzmann et al., 2011). T. Smith is predicting that, as all content moves into the web then social media and consumer opinion will increasingly define the future of not just the web, but society as a whole (Smith, 2009). Table 1 presents the main points of reference being the basis definitions indicated by the authors.

Tahle 1. Main point of reference in the proposed social media definition

\begin{tabular}{|c|c|c|}
\hline Years & The Authors of social media definitions & Main point of reference in the proposed definition \\
\hline 2007 & Danah Boyd, Nicole Ellison & gaining a new contacts \\
\hline 2009 & Safko, Brake & sharing information, knowledge, and opinions using conversational media \\
\hline 2010 & M. Kaplan, M. Haenlein & applications that allow the creation and exchange of user-generated content \\
\hline 2010 & Van Dijk & the idea of creating content and sharing it with other users \\
\hline 2010 & Ph. Kotler & applications creating interaction between users \\
\hline 2011 & Kietzmann, Hermkens, McCarthy, Silvestre & dialogue between market users \\
\hline 2012 & A.Czubała & interaction, integration and personalization sites by users \\
\hline 2012 & K. Fabjaniak-Czerniak & Communications recipients various social groups by improved mobile applications tools \\
\hline 2013 & M. Jurkowski & multidirectional communication in the exchange of experience \\
\hline 2013 & Nguyen, Phung, Adams, Venkatesh & media in which users assume a myriad of roles \\
\hline 2014 & D. Kaznowski & media subject to social control \\
\hline 2014 & M. Czaplicka & users interaction \\
\hline 2015 & T. Dryl & $\begin{array}{l}\text { media subject to social control and the dialogues between participants in the communication } \\
\text { process }\end{array}$ \\
\hline 2016 & Authors definition & $\begin{array}{l}\text { Communication channels enabling the exchange of information, interaction and/or integration } \\
\text { between the community network, which determines the communiqué availability }\end{array}$ \\
\hline
\end{tabular}

Source: own elaboration.

Based on analysis of existing definitions, as well as emerging and changing form of social media, the authors proposed his own definition of social media.

Social media is network community communication channels, allowing for the exchange of information, but also interaction or integration between network users (Internet users), or Internet users and brands. Published information is available to all users or to selected groups and undergo less or more social control.

The authors in the definition focused on three main aspects which relate to social media:

- communication channels network community - like every traditional media, network media have their communication channels - websites, blogs, microblogs, forums, etc.

- opportunities and the way of activities of individual channels - individual communication channels have different opportunities to involve network community. Sometimes it is only the transfer of information, other times interaction with or without integration of users, or users with brands.

- decides network community of the access to the communiqué - a community network determines the availability communiqué. 


\section{Conclusions}

Social media have undeniably transformed and changed the character of private and public communication. Today, many companies all over the world operates only through the social media channels (online). To define the meaning of social media is of a great importance especially from the marketing point of view and it's communication perspective. Authors of this article have proposed the definition, that describes social media, as network community communication channels, allowing for the exchange of information, but also interaction or integration between network users (Internet users), or Internet users and brands. Published infor-mation is available to all users or to selected groups and undergo less or more social control.

\section{References}

Asur, S. \& Huberman, B.A. (2010). Predicting the Future with Social Media. WI-IAT'10 Proceeding of the 2010 IEEE/WIC/ACM International Conference on Web Intelligence and Intelligent Agent Technology, Vol. 1, 492-499.

Bloom, P.N. \& Novelli, W.D. (1981). Problems and Challenges in Social Marketing. Journal of Marketing, 45 (2), 79-88.

Braten, J. (1981). Modeller av menneske og samfunn: Bro mellom teori og erfaring fra sosiologi og sosialpsykolologi (On models of man and society). Oslo: Universitetsforlaget.

Castells, M. (2000). The Rise of The Network Society: The Information Age: Economy, Society and Culture. West Sussex: John Wiley \& Sons.

Czubała, A. (2012). Podstawy marketingu. Warszawa: Polskie Wydawnictwo Ekonomiczne.

Dijck, J. (2013). The Culture of Connectivity. A Critical History of Social Media. New York: Oxford University Press, 7, 14, 30, VII Acknowledgement.

Dryl, T. (2015). Serwisy społecznościowe Web 2.0 jako przykład innowacji w marketingu. Logistyka, 2 (CD2), 1181-1189.

Edosomwan, S., Prakasan, S.K., Kouame D., Watson J. \& Seymour, T. (2011). The History of Social Media and its Impact on Business. The Journal of Applied Management and Entrepreneurship, 16 (3).

Fabjaniak-Czerniak, K. (2012), Internetowe media społecznościowe jako narzędzie public relations. In: K. Kubiak (ed.), Zarządzanie w sytuacjach kryzysowych niepewności (pp. 173-194). Warszawa: Wyższa Szkoła Promocji.

Gracz, L. \& Ostrowska, I. (2014). Młodzi nabywcy na e-zakupach. Warszawa: Placet.

Jurkowski, M. (2013). Portale internetowe zakupów grupowych - ich potencjał rozwojowy i szansa taniego podróżowania. Koszalin: Politechnika Koszalińska.

Kaplan, A.M. \& Haenlein, M. (2010). Users of the world, unite! The challenges and opportunities of Social Media. Business Horizons, $53(1), 59-68$.

Królewski, J. \& Sala, P. (eds.). (2016). E-marketing. Współczesne trendy. Pakiet startowy. Warszawa: Wydawnictwo Naukowe PWN.

Kietzmann, J.H., Hermkens, K., McCarthy, I.P. \& Silvestre, B.S. (2011). Social media? Get serious! Understanding the functional building blocks of social media. Business Horizons, 54 (3), 241.

Kotler, Ph. (1975). Marketing for nonprofit organizations. New York: Englewood Cliffs, Prentice-Hall.

Kotler, Ph.\& Zaltman, G. (1971). Social Marketing: An Approach to Planned Social Change. Journal of Marketing, 35 (3), 3.

Martin, J. (1978). The Wired Society. A challenge for tomorrow. London: Prentice Hall.

McGinniss, J. (1969). The Selling of the President 1968. New York: Trident Press.

Michaelidou, N., Siamagka, N.T. \& Christodoulides, G. (2011). Usage, barriers and measurement of social media marketing: An exploratory investigation of small and medium B2B brands. Industrial Marketing Management, 40 (7), 1153-1159.

Mróz-Gorgoń, B. (2014). Marketing aspects of using social media by fashion brands in Poland. Human Capital without Borders: Knowledge and Learning for Quality of Life. Management, Knowledge and Learning International Conference, 25-27 June. Portorož, Slovenia: ToKnowPress.

Peszko, K. \& Chrąchol, U. (2011). Możliwości social media - znajomość pojęć a użytkowanie. Zeszyty Naukowe Uniwersytetu Szczecińskiego, 666, Problemy Zarządzania, Finansów i Marketingu, 19, 93-102. 
Shirky, C. (2011). The political power of social media. Foreign Affairs, 90 (1), 28-41, 274.

Smith, T. (2009). The social media revolution. International Journal of Market Research, 51 (4), 561.

Szymański, G. (2013). Innowacje marketingowe w sektorze e-commerce. Łódź: Wydawnictwo Politechniki Łódzkiej.

Szymański, G. \& Kowalczyk, A. (2012). Rola aplikacji rynkowych Fecobooka we współczesnych strategiach marketingowych. Studia Informatica, 31, 274.

Wiebe, G.D. (1951). Merchandising Commodities and Citizenship on Television. Public Opinion Quarterly, 15 (4), 679.

Cite this article aS: Mróz-Gorgoń, B., Peszko, K. (2016). Marketing analysis of social media - definition considerations. European Journal of Service Management, 20 (4), 33-40. DOI: 10.18276/ejsm.2016.20-04. 